\title{
The "Mourning" Of the Land as Occasioned by Oil-Mineral- Pollution in the Niger Delta of Nigeria.
}

\author{
Ucheawaji G. Josiah, Gogonte H. Amah \\ (Department of Religious Studies, School of Education and Humanities, Babcock University, \\ Ilisan Remo, Ogun State, Nigeria) \\ (Department of Biochemistry, Benjamin Carson School of Medicine Babcock University, \\ Ilisan Remo, Ogun State, Nigeria)
}

\begin{abstract}
The converging of world leaders at the United Nations in September 2000, and their signing of the Millennium Declaration with the target of meeting the Millennium Development Goal of 'environmental sustainability' by 2015, is an indication that the 'land' is 'mourning.' This paper investigates the usage of the

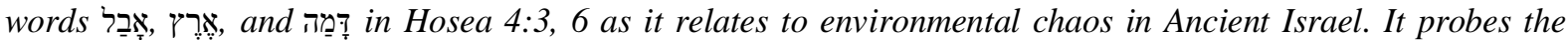
extent to which the eastern Rivers State of the Niger Delta is 'mourning.' It delineates that there are ecological zones within the Niger Delta region that are contending with detrimental level of Oil-mineral pollution assault at least in the aquatic ecosystem and, most likely, the terrestrial; as there is significant level of oil-mineral pollutant in not only the water samples but also the sediment samples analyzed in this work with the use of Standard Analytical Procedure (Spectrophotometrically). It concludes that, the population groups (including humans and animals) that depend on the affected water to serve their water needs stand highly susceptible to hydrocarbon toxicity, with its varied attendant health and ecological implications. It further submits that (total destruction) is inevitable should the region be left to continuous 'mourning.'

Furthermore, the paper submits that could be inevitable should the region be left to continuous "mourning" resulting from Oil-mineral pollution, though not precluding moral laxity which was the case of Ancient Israel. Keywords: Aquatic Ecosystem, Eastern Rivers State, Hydrocarbon pollutant, Hosea 4, Mourning
\end{abstract}

Accepted Date: 04 Nov 2013

\section{Introduction}

In the midst of chaos, אֶלדים (' $\mathrm{l}$ lōhim) - God is said to have created the cosmos by establishing order. Furthermore, in Gen. 1:4, the earth is portrayed in its perfection, using the descriptive Hebrew - tob (good) which according to Vines means 'wellbeing of a situation or thing.' It could be of land, agricultural goodness or fertility (see, Exodus 3:8). It also denotes life support, and potential for productivity, which may be pleasant, delightful as well as fruitful. Unfortunately, that 'orderly' and 'goodly' earth has been ruthlessly treated to the extent that it has become an issue of global concern.

The converging of world leaders at the United Nations in September 2000, and their signing of the Millennium Declaration with the target of meeting the Millennium Development Goal of 'environmental sustainability' by 2015 , is an indication that the environment is 'mourning' and needs to be 'comforted'. It is indeed becoming increasingly obvious that environmental issues affect humanity to a degree as probably never thought of earlier than now. Even the Niger Delta Region of Nigeria is not spared either. Addressing the effect of damage on the environment, Sharma states that the ecosystems are no longer safe; that their unsafe condition has largely been engendered by the activities of humans. But how can the land 'mourn?' To what extent is the Niger Delta land 'mourning' as a result of oil mineral related environmental pollution? It is therefore against this backdrop, that this work seeks to explore the extent to which the Niger Delta land is "mourning" using the Hebrew text of Hosea $4: 3$ as the springboard.

Land as used in this context is not limited to the terrestrial ecological span, but includes all that could be regarded as being enveloped by natural biosphere such the arboreal, aquatic, and terrestrial habitat. It may not necessarily be synonymous with its economic usage as a factor of production.

\section{Background to Hosea 4}

The book of Hosea 4 presents a devastating, degrading, and chaotic condition of the ancient Israel's environment. It thus implies that moral laxity in the social realm of life is a direct causative agent for ecological degradation in Israel. This supposition however, has received interest of scholars such as Wolf, Mays, and Anderson who associate the "mourning" of Israel's land directly with moral decay in the society. Consequent on 
that, one may wish to understand how moral laxity could be a direct consequence for the 'mourning' of Israel's land as shown in the text. It may also be of interest to know whether there is a well defined link between lack of social Justice and ecological damage though this is not the focus of this paper.

The kingdom of Israel under the leadership of Jeroboam II was preoccupied with the facets of what scholars referred to as the "good life" (Amos 6:4-6), but when Jeroboam II died, Israel quickly sank into a period of Bloodshed and confusion from which it never recovered. Hoerth observes that the peaceful period of Israel during Jeroboam's reign was partly a result of Assyrian weakness. But during the reign of Menahem king of Israel, it dawned on them that weakness in the part of Assyria has ended. This was so because Assyria had found a strong leader in Tiglath-pileser III (the Biblical Pul, 2Kings 15:19-20). Hoerth presents the underlying boastful words of Tiglath-pileser as seen below:

I received tribute from...Rezon of Damascus, Menahem of Samaria, Hiram of Tyre... to wit: gold, silver, tin, iron, elephant hides, ivory, linen garments with multicolored trimmings, blue-dyed wool, purple-dyed wool, ebony wood, boxwood, whatever was precious enough for royal treasure; also lambs whose stretched hides were dyed purple and wild birds whose spread-out wings were dyed blue, furthermore horses, mules, large and small cattle, male camels, female camels with their foals.... As for Menahem (King of Israel) I overwhelmed him like a snowstorm and he fled like a bird, alone, and bowed to my feet. I returned him to his place and imposed tribute upon him, to wit: gold, silver, linen garments with multicolored trimmings.

Hoerth gives a run down on how Israel little by little faded away. He states that as at $722 \mathrm{BC}$, the country of Israel ceased. And it was as a result of King Hoshea's disloyalty to the Assyrian king (2 Kings $18: 11)$

Conversely, Wolff blames two groups in the Israelites' society for the ecological crises of Hosea 4:3'the mourning of the Land' He identifies these groups as religious as well as political. The priests, he posits

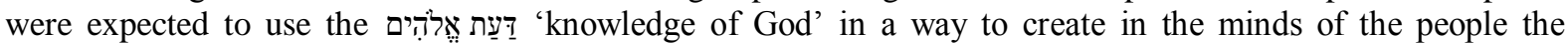
certainty of God's saving action and justice, while the political leaders were to formulate and execute foreign policies in accordance with the will of Yahweh, yet these groups failed in their duties and became culpable of the sins of 'omission' and 'commission' as Andersen puts it.

Andersen further elucidates his claims by stating that Hosea 4:1(b) enumerates those sins of omission as lack of "integrity, mercy, knowledge of God in the land" whereas that of 'commission' he identifies as 'swearing, lying, killing, stealing and committing adultery' (Hosea 4:2). But how can lack of integrity, mercy, knowledge of God in the land be detrimental to ecological wellbeing? Is the environmental crisis in the Niger Delta region a "cult" inflicted crisis? Or could it be politically inclined?

In the same vein, Mays adds that the Northern Kingdom had already sunk to the level of a chaotic society due to the proliferation of such crimes as 'swearing, lying, killing, stealing and committing adultery'. Social violence he holds, had become the content of their life as Hosea eloquently puts it, no moment was left free of their crime as one bloody deed followed another (Hosea 4:2b).

In a nutshell, the lack of 'faithfulness, devotion and the knowledge of God' in the spheres of both religion and politics in the Northern kingdom of Israel led to an outbreak of 'stealing, killing, lying,' and so on, (sins of commission) which in turn attracts an equivalent public concrete disaster as enshrined in Hosea 4:3- 'the mourning of the land,' an obvious ecological disaster brought to fruition by the Assyrians at about 721 B.C

\section{3. (i) aesoH 4: 3 אבֵּל $\left.{ }^{\circ}{ }^{\circ} \mathrm{bal}\right\}$ (Mourning)}

The word אָָָ -has its etymology in the Ancient Near East. The root 'bl occurs in several Semitic languages but with different meanings. It is in contrast with the Akkadian- abalu "to dry (up)." In other languages like Arabic, there are words from this root ' $b l$ which are connected with 'mourning' and 'illness.' אָבַל is used as synonym of yabash, 'to be dry, to dry up' (Jeremiah 12:4; 23:10; Joel 1:10), 'umlal 'to be feeble, languish' (Isaiah 19:8; 24:4,7; 33:9; Hosea 4:3), qadar 'to be dark' (Psalm 35:14; Jeremiah 4:28), bākāh, 'to weep, lament' (Amos 5:16;Micah 1:8). אָָָ could be used in connection with 'mourning' for the dead. When used in connection with the dead אָָָ does not describe the inner feelings of the mourner but his outward behavior. For example, in Genesis 37:34; 2Samuel 13:31-37 where this word occurs, it makes reference to ancient custom which include putting on sackcloth ( $s a q)$, sprinkling dust and ashes on the head, lying on the ground, and shaving the beard and the hair of the head. אָּ in this regard is clearer a technical term for all of these customs together that might be observed in case of a death.

When used in connection with announcement of judgement, אָָ could be understood as 'mourning' over those who have perished. In Hosea 4:3, אָ occurs as a reaction to judgement. It takes place with reference to a possible change of things.

With reference to nature and vegetation, אָָ is said to be linked with calamity which has come upon the land. In other words, even nature participates in the humiliation, that is, 'diminution' of the people struck with the calamity. 


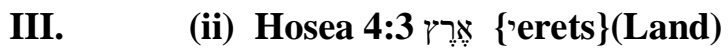

Could mean 'earth' or 'land.' It occurs some 2505 times in the Old Testament, having a broad range of meaning: from the whole earth, through particular countries, especially the land of Israel, local districts, the soil, to the ground inside the tent (Joshua 7:21). It could mean human dwelling. Although God is the universal owner of the earth, the more direct fact is that the earth is where human beings live (Psalm 115:16). In the creation

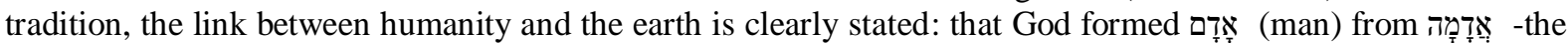
dust of the earth (Genesis 2:7). When personified, אֶרץ can refer to the whole earth, to the land of Israel, or to their inhabitants depending on the context, which is usually clear. In the Scriptures, we see a link between human evil and environmental damage. Human evil and injustice make the land 'mourn' (Hosea 4:3), and cry out and weep (Job 31:38), and most vividly of all, even vomit (Leviticus i8: 25-28). However, 'land' as used in this paper, rather than connoting the whole earth, or Israel's land, is used in a context not limited to the terrestrial ecological span, but includes all that could be regarded as being enveloped by natural biosphere such the arboreal, aquatic, and terrestrial habitat. It may not necessarily be synonymous with its economic usage as a factor of production.

\section{Incidents Of Oil Mineral Pollution In Niger Delta}

Onuorah, Nwaomah, Spalling and others have observed that the Niger Delta 'land' is degraded due to oil exploration in the area.

Accordingly, Okaba writing on the predicament, caused by oil spills, gas flaring, dredging of canals, barrow pits, and land take for construction facilities sums up the environmental impact of the oil industry in the Niger Delta of Nigeria as land deprivation, soil quality alteration, and destruction of aquatic ecosystem and air pollution. These environmental conditions are caused by a collection of oil exploration and exploitation activities such as construction of flow lines and trunk line networks, terminals, digging of location waste pits and barrow pits, and oil spillage either from equipment failure, human error, corrosion of pipes due to age and sabotage.

Furthermore, a diminutive clue to the rate of this damage is revealed in a recent report submitted by the United Nations Environmental Programme (UNEP) on the Niger Delta, particularly the Ogoni-land. The report revealed a great deal of degradation. This fourteen-month scientific assessment of the Niger Delta - Ogoni land to be precise - reveals the following findings:

1. Surface water contamination and up to eight centimeters in underground water that feed drinking wells at fourteen sites.

2. The water is said to have contained dangerous concentration of benzene (toxic liquid from petroleum) and other harmful chemicals;

3. Soil contamination of more than five meters deep in many areas.

Although the UNEP has recommended the need for the provision of initial \$1billion for the clean-up of the area which would last 30 years, the fact remains that the Niger Delta land is indeed facing degradation.

\section{Nigerian Government Attempts Towards Curbing Oil-Mineral Related Environmental Pollution}

In response to pollution, Abodunrin outlines government's prominent legislation on pollution resulting from petroleum exploration. He enumerates those Acts as follows:

1. Oil pipeline Act 1958

2. Petroleum regulation of 1967

3. Oil in navigable waters Act No 34, 1968

4. Oil in navigable waters regulation of 1968

5. Petroleum Act of 1969

6. Petroleum (drilling and production) regulation of 1969

7. Petroleum (drilling and production) Amendments Regulation of 1973

8. Petroleum Refining Regulations of 1974.

In essence, these acts were given as a check on pollution and yet, the Niger Delta land has been and is being engulfed with pollution.

Few years ago, the federal government came up with the idea of a 'Ministry' for the Niger Delta Affairs. In the same vein, the UNEP has recommended the need for the provision of initial \$1billion for the clean-up of the Ogoni-land of the Eastern Rivers zone of the Niger Delta Region which will take 30 years (a generation) to clean. But the fact remains that in spite of all these measures, the Niger Delta 'land' continues to "mourn." Nevertheless, some groups in the Niger Delta region having seen the need for 'sustainability' once resorted to a struggle for resource control as a means for saving the region from its plight, yet to no avail. Dada 
had noted that the Niger Delta region is faced with structural injustice which has caused devastating physical damage on the environment. The obvious observation is that the Niger Delta region is "mourning." The next segment tabulates empirical evidences for Oil-mineral pollution in Eastern Rivers State of the Niger Delta Region of Nigeria.

\section{Empirical Evidence for Oil-mineral pollution in the Niger Delta}

The level of oil-mineral pollution in water and sediment was assessed in course of this study, using ten locations selected at random within the Eastern Rivers State in the Niger Delta as study sites. Water and sediment samples were collected and analyzed in triplicate, using standard analytical procedure (spectrophotometrically).

The location for sample collection span from Amadi creek, which empties into the upper Port Harcourt River; through the Port Harcourt-Bonny confluence; through Upper Andoni River to Kono River (in Ogoni zone) via Opobo River. Since it was impracticable to collect samples at every quadrant along the route, only representative locations were selected along the route for sample collection. The location sampled and a summary of the findings thereof are presented in the table below.

Table 1:

Level of Oil-mineral Pollutant in Water and Sediment Sampled from Selected Locations within Eastern Rivers State. Values are recorded as mean values of the triplicate.

\begin{tabular}{|l|l|l|l|}
\hline S/No. & Location & Water $(\mathbf{p p m})$ & Sediment \\
\hline 1 & Agbakwañ $)$ \\
\hline 2 & Kono Waterside & 4.36 & 798.30 \\
\hline 3 & Asarama Creek & 3.80 & 571.60 \\
\hline 4 & Oyorokoto River & 3.22 & 358.60 \\
\hline 5 & Ngo Confluence & 3.20 & 365.30 \\
\hline 6 & Bonny Loading Jetty & 3.15 & 339.10 \\
\hline 7 & Upper Nkoro River & 1.48 & 117.30 \\
\hline 8 & Opobo River & 1.34 & 87.60 \\
\hline 9 & Inyoñorong-Nkoro Confluence & 1.12 & 37.80 \\
\hline 10 & Amadi Creek & 0.90 & 48.70 \\
\hline
\end{tabular}

The above result shows the level of oil-mineral pollutant (in parts per million, ppm) as at the time the study was conducted, within the areas covered by the study. Agbakwan Asarama, Kono waterside, Asarama creek, Oyorokoto River and Ngo confluence empirically show significant level of oil-mineral pollutant assault. However, Bonny Loading Jetty, Upper Nkoro River, Opobo River, Inyonorong-Nkoro confluence, and Amadi Creek were recorded to have insignificant level of oil-mineral pollutant assault.

The foregoing experimental data vividly delineate that there are ecological zones within the Niger Delta region that are contending with detrimental level of oil-mineral pollution assault, at least in the aquatic ecosystem and, most likely, the terrestrial; as there is significant level of oil-mineral pollutant in not only the water samples but also the sediment samples analyzed. Such high level of hydrocarbon pollutant has been associated with severe health implications for affected populations. The economic activities of the human population group that depend on such water sources for livelihood (fish farmers) have been negatively affected. This stems from the depletion of the preoccupying fish species either by death or migration to safer ecological zone. Moreso, the population groups (including humans and animals) that depend on the affected water to serve their water needs stand highly susceptible to hydrocarbon toxicity, with its varied attendant health and ecological implications.

The above extrapolation is affirmed by the claim of Emma Amaiza that five persons, including a mother of six from some riverine communities of Niger Delta, have been hospitalized after drinking suspected contaminated water from a river, allegedly polluted by Agip Oil Company in course of dredging activities in the communities'. He proceeds in his statement that the pollution has also affected the water such that the fishing occupation of the people is stalled. If this is left to continue, there might be "ș "silence" as Hosea prescribes My people perish, (are destroyed, ruined, or gone into silence) (Hosea 4:5, 6).

Nevertheless, the silence that the verb דָּ produces is in most instances, total. The New International Version (NIV) of the English Bible translates this word 12 times to mean 'destroyed,' 'ruined,' or 'perished.' In fact, in Hosea 4, the verb is used in the Niphal form to describe the results of divine judgment. The same word is used in the same form in Psalm 49: 12, 20, 21, of a foolish rich man who is 'like the beast that perish $(d m h)$.' 
This is an appropriate reminder that like the beast, such a person will succumb to death. Death becomes his shepherd (Psalm 49: 15, 16), and will separate him from his riches (Psalm 49: 10, 14, 17)..

\section{Conclusion}

There are incidences of oil-mineral pollution within the Niger Delta region of Nigeria that are not receiving equivalent environmentally remedial attention and such negligence or oversight (as the case may be) further heightens the degree of ambient ecological deterioration in the Niger Delta. Also, although the region is highly predisposed to pollution assault occasioned by hydrocarbon (oil-mineral and related products), the different parts of the region is exposed to the pollutant at differing magnitudes; some much more susceptible than the others.

In Hosea 4:3, 5-6, אבר (mourning) and (silence, ruin, destruction) occur as a reaction to judgment. It takes place with reference to a possible change of things. However, in the Rivers East of Niger Delta of Nigeria, with reference to the land (aquatic), אָָ could be said to be linked with calamity which has come upon the land (aquatic) that has affected both man and the aquatic life as Emma Amaize has noted above. In other words, even nature participates in the humiliation, that is, 'diminution'calamity.

Therefore, it is also conclusive that the Niger Delta 'land' (at least, the Eastern Rivers fraction) is 'mourning', lamenting its assault by oil-mineral pollution- dangerously high level of hydrocarbon. Given this submission, if the Rivers State East of the Niger Delta region of Nigeria, is left to continuous 'Mourning' due to oil-mineral pollution, (total silence (death), ruin, destruction) could be the aftermath consequence. The foregoing asserts that the 'land' of Eastern Rivers State in the Niger Delta region of Nigeria is indeed 'mourning' perhaps due to naivety, and poor technical knowhow in environmental management but not precluding moral laxity.

References

[1]. The researchers are both from the eastern Rivers State of the Niger Delta Region, precisely from Andoni, a coastal region in Rivers State. The burden of this paper stems from the fact that fishing as the occupation of the Obolo people, that is, the Andoni people , has been hampered by oil-mineral pollution such that survival becomes difficult although the issue of oil-mineral pollution may not make sense to the illiterate fishermen or women back there in the village.

[2]. Ibid. Von Rad, G. Genesis: A Commentary, (London: SCM Press, 1966), p.49.

[3]. W. E. Vines, Vine's Complete Expository Dictionary of Old and New Testament Words With Topical Index (London: Thomas Nelson Publishers, 1996), p. 8064.

[4]. Narendra P. Sharma, "Introduction” Managing the World's Forest (Iowa:Kendall/Hunt Publishing Company, 1992), p.1.

[5]. Hans Walter Wolff, Hosea: A Commentary on the Book of the Prophet Hosea, (Philadelphia: Fortress Press, 1974), pp. xxvi-xxvii.

[6]. James Luther Mays, Hosea: A Commentary, (Philadelphia: The Westminster Press, 1969), pp. 12-13

[7]. Francis I Anderson, Hosea: A New Translation with Introduction and Commentary,( NY: Doubleday Dell Publishing Group, Inc., 1980) pp.331-341.

[8]. Stanley J. Grenze, (et.al), Pocket Dictionary of Ethics, (Downers Grove, IL: Inter Varsity Press, 2003), p. 111. Here, social Justice is portrayed as the application of the more general category of justice to a central dimension of human existence. It focuses on the common good of community as it is manifested in such areas as the fair and equal distribution of goods and benefits as well as in respect for the rights of others.

[9]. Alfred J. Hoerth, Archaeology and the Old Testament, Reprinted 2004, (Grand Rapids, MI: Baker Books, 1998), pp.329-335.

[10]. Hans Walter Wolff, op.cit, pp. xxvi-xxvii.

[11]. Francis I. Andersen, op.cit, pp.331-341. Mays, op.cit, p.65

[12]. E. W. Heaton, The Old Testament Prophets (Edinburgh: R\&R. Clark Ltd., 1958), p.18.

[13]. Arnulf Baumann, Hannover בָבָ in Botterweck G. Johannes (Ed.) Theological Dictionary of the Old Testament, Vol. 1, (Grand Rapids, MI: William B Eerdmans Publishing Company, 1990), pp. 44-48

[14]. William A. VanGemeren (Ed.), New International Dictionary of Old Testament Theology and Exegesis, Vol. 1, (Grand Rapids, MI: Zondervan Publishing House, 1997), pp. 518-519.

[15]. M. Onuorah, "UNDP Deplores Poverty Level in Niger Delta" The Guardian, (July 19, 2006).

[16]. S.M. Nwaomah, "Biblical Ecology of Stewardship: Option in Quest for Sustainable Environment in the Niger Delta Region of Nigeria" The Living Word: Journal of Philosophy and Theology, Vol.113/2, (March- April, 2007), pp. 89-103.

[17]. Harry Spalling et.al "Earthkeeping and the Poor: Assessing the Environmental Sustainability of Development Projects," Perspectives on Science and Christian Faith, 53(3), 2001, pp.142-151.

[18]. B. O. Okaba, Petroleum Industry and the Paradox of Rural Poverty in the Niger Delta, (Benin City: Ethiope Publishing, 2005), 1820. See also Nwaomah S.M, Biblical Ecology of Stewardship pp. 89-103; Sampson M. Nwaomah, "Water in the Bible in the Context of the Ecological Debate in the Nigerian Delta." The Journal for Faith, Spirituality and Social Change. Vol. 1. I. Issue 2 (May 2008), pp. 187-204; and "Eschatology of Environmental Bliss in Romans 8:18-22 and the Imperative of Present Environmental sustainability From a Nigerian Perspective" paper read at the WGREN Conference, Ohio Northern University, Ada, Ohio, April 17-19, 2009.

[19]. Emmanuel Affonne, "Ogoni: Justice at Last" in Nigerian News World vol.15, No. 025, (August 22, 2011), pp14-20. www.nigeriannewsworld.com .

[20]. A. O. Abodunrin, "Anti-Pollution Laws in Deut 23:13-14" in Prof. Chris Ukachukwu Manus (Ed.) Biblical Studies and Environmental Issues in Africa, A Publication of the Nigerian Association of Biblical Studies (NABIS), NABIS West Biblical Studies, vol.1, (2008), p. 143 (137-145).

[21]. Clement Ikpat, et.al, The Niger Delta Problems and Solutions: The Equilateral Resource Control (ERC) model as an Alternative Dispute Resolution (ADR) concept (2001). http://nigerdeltacongress.com/narticles/niger delta_problems and solutio.htm , accessed 5th June, 2011. 
[22]. Adekunle Oyinloye Dada, "Prosperity Gospel in Nigerian Context: A Medium of Social Transformation Or An Impetus for Delusion? In ORITA: Ibadan Journal of Religious Studies, XXXVI/1-2, June and December, 2004, pp.95-107.

[23]. Emma Amaiza, 'Polluted water by oil firm lands five villagers in hospital' Vanguard, (Thursday, March 29, 2012). p.cit, New International Dictionary of the Old Testament, vol.1, p 971. 